\title{
THE PHYSICAL CHARACTERISTICS OF RICE STRAW, WOOD SHAVINGS AND SAND AS BEDDING MATERIALS AND THEIR EFFECTS ON LAMBS' PERFORMANCE AND WELFARE
}

\author{
A.M.A. Hussein \\ Department of Animal Production, Faculty of Agriculture, Assuit University, Assuit, Egypt 71515
}

Received: $25 / 12 / 2016$

\section{SUMMARY}

The aim of the present study is to evaluate the effect of using sand and wood shavings as alternative bedding materials other than rice straw, on lambs' welfare and productive performance during the growing phase. Eighteen Baladi lambs (fed ad libitum with concentrate) were assigned to individual pens containing one of three bedding materials in replicates of six lambs for five months. Bedding samples were weekly collected to estimate the physical characteristics of different bedding materials. Moreover, pen cleanliness was scored weekly and fleece cleanliness scored at the end of the experiment. Live body weight and feed intake were recorded. Consequently, daily gain and feed conversion ratio were calculated. Blood samples were taken monthly and serum total protein, albumin, and cortisol were measured. Sand had lower absorbency and surface temperature $(P<0.05)$ in hot months compared with other two groups. On the other hand, sand had the highest $(P<0.05) \mathrm{pH}$ value and dry matter. Lambs in sand group consume more $(P<0.01)$ dry matter and efficiently $(P<0.05)$ converted dry matter intake to daily gain compared with lambs in the other two groups. In addition, lambs in sand group had greater $(P<0.05)$ daily gain compared to the other two groups, which led to be of eavier $(P<0.05)$ final body weight. Serum total protein, Albumin and cortisol levels were higher $(P<0.05)$ in wood shavings group than the other two groups. The study concluded that sand improves animal comfort and performance and can be considered a good bedding materials for lambs during growing period.

\section{Keywords: Bedding type, lambs' performance, blood parameters, physical characteristics}

\section{INTRODUCTION}

The influence of different bedding types on the health, behavior and performance of dairy cattle has been extensively researched (Tuyttens, 2005). On the other hand, less information is available about the effect of bedding materials on sheep (Gordon and Cockram, 1995 and McGreevy et al., 2007). Bedding material is an important factor, which is permanently used during the farm animal's lifetime (Teixeira et al., 2013). Bedding materials should provide good animal welfare and productivity, by providing insulation, warmth, and comfort to housed (Tuyttens, 2005 and Norring et al., 2010). Moreover, it should keep the animal dry, clean and healthy by absorbing moisture and inhibiting bacterial growth to minimal level (O 'Connell and Meaney, 1997). Sawdust, wood shavings, straw, and sand are the most common beddings used in sheep industry. Sawdust, wood shaving and straw are organic materials, while sand is inorganic material. Cereal straw is the most traditionally used bedding material for lambs, which also serves as forage (Teixeira et al., 2012). Straw is a by-product from agricultural fields and is the most common used bedding material (Ericsson and Nilsson, 2006). The use of straw bedding in lamb housing has a number of advantages in lamb welfare. Where, straw is providing comfort, encouraging the normal behavior (Teixeira et al., 2012). On the other hand, straw as bedding has some disadvantages. Where, it increases production costs. Moreover, straw is incompatible with liquid manure handling systems, (Tuyttens, 2005) and its chemical and microbiological characteristics are changed quickly after use (Teixeira et al., 2014).

Consequently, there is a need for alternative bedding materials for housed lambs. Wood shavings can be used as an organic bedding material instead of straw. wood shavings have unique characteristics compared with other bedding materials. Wood shavings have a higher lignin content which takes longer time to decompose (Bollen and Lu, 1957). Moreover, wood shavings contain other organic chemicals such as phenols, organic acids, tannins, resins, and turpentine (Miller et al, 2006). Consequently, these organic chemicals in wood shaving are working as natural antibacterial inhibitors (Allison and Anderson, 1951). For example, wood shavings bedding in cattle manure decreased the survival times for E. coli (Kudva et al., 1998). In addition, Nimenya et al. (2000) reported that sawdust inhibited urease producing bacteria which convert urea to ammonia in dairy cattle urine. The authors imputed this bacterial inhibition to the wood's tar content. In addition, sand, which is inorganic material and considered to have many advantages as a bedding material for housed animals comfort and welfare. Firstly, sand can improve the animal health because it has low bacterial counts compared with organic bedding materials. Secondly, it can conduct heat away from the animal. Finally, sand has a loose texture that provides soft surface for animal to lay on (Bewley et al., 2001). The aim of present study is to evaluate the effect of using two alternative bedding materials other than straw, on lambs' welfare and productive performance during the growing phase. 


\section{MATERIALS AND METHODS}

\section{Animals and treatments:}

This study was conducted at Animal Production Department's farm, Faculty of agriculture, Assuit University. The experimental period lasted for 5 months from the beginning of August to the end of December (2015). Eighteen Baladi lambs (Saidi breed) with 6 months of age and average body weight $26 \mathrm{~kg}$ were used. All lambs were weighed on the beginning of the experiment, blocked in descending order of weight. Lambs were allocated to one of the three treatment groups of six replicates (rice straw, sand or wood shavings bedding material) at random within each block. Therefore, each treatment contained lambs that covered the full range of weights available. Nine individual pens of $2.42 \mathrm{~m}^{2}$ were assigned within each of two stables, to give a total of 18 pens. Three pens within each stable were allocated at random to one of the three bedding materials. Rice straw, sand and Wood shavings bedding materials were initially laid to a depth of approximately $10 \mathrm{~cm}$ over a cement base-mat. Bedding materials were added to each pen weekly after bedding data were recorded. Materials were visually added to maintain the desired depth of bedding in the pen. Fresh rice straw, sand and fresh wood shavings were laid monthly. Water, wheat straw and concentrates were supplied ad-libitum in buckets. Daily rations consisted mixture of $20 \%$ wheat straw as roughage and $80 \%$ a concentrate mixture of $42 \%$ corn, $30 \%$ wheat bran, $25 \%$ Decorticated cotton meal, $1 \%$ salt and $2 \%$ a mineral vitamin premix.

\section{Bedding physical characteristics:}

Bedding samples were collected to measure DM, absorbency and $\mathrm{pH}$ on day 0 and at seven days intervals throughout the month. Samples on day seven, 14,21 , and 28 were taken with plastic gloves to remove material from five subsampling sites in each pen (four around the perimeter and one from the center) using paper cups. These subsamples from each pen (from 100 to $140 \mathrm{~g}$ of the bedding materials) were composited and placed into sterile plastic bags. Upon arrival at the laboratory, $20 \mathrm{~g}$ of the bedding sample were removed and analyzed for $\mathrm{DM}$ by drying in an oven at $100^{\circ} \mathrm{C}$ for $24 \mathrm{hrs}$. Five grams (ambient weight) were removed and mixed with $45 \mathrm{ml}$ of deionized water for $20 \mathrm{~min}$ to analyze $\mathrm{pH}$ with a $\mathrm{pH}$ meter, and then left for $3 \mathrm{hrs}$. to allow absorption of water. After 3 hrs., excess water was poured from the sample and a wet weight was obtained(Zehner et al., 1986). Absorbency was calculated by the equation: Absorbency $=\{$ (wet weight - ambient weight) x 100$\} /$ ambient weight (Zehner et al., 1986).

Pen cleanliness was scored weekly while the lambs were being out. A score of five was dry and clean, 4 was 20 to $40 \%$ of surface dirty or wet, 3 was 40 to $60 \%$ of surface dirty or wet, 2 was 60 to $80 \%$ of surface dirty or wet, and a score of 1 was more than $80 \%$ of surface dirty or wet (Panivivat et al. 2004).
Surface temperature of the bedding material at the front, rear and the middle was measured weekly on the same day and time as pen cleanliness, by a digital thermometer (Raynger ${ }^{\circledR} \mathrm{ST}^{\mathrm{TM}}$, Santa Cruz, CA).

\section{Lambs'performance:}

At the end of the experiment, all the lambs were assessed and scored on visual cleanliness of the fleece. The MHS categories for woolly lambs (1- 5 scale) shown in Hadley et al. (1997) was used. The score ' 1 ' represented a visually Clean, dry fleece with only a small amount of adherent bedding; score ' 5 ', represented extensive soiling of the complete underside and all four limbs with wet, dripping faecal material. Daily feed intake was recorded during the experimental period. Body weight was recorded at the beginning of the experiment and subsequently, every two weeks. Accordingly, daily gain and feed conversion were calculated biweekly.

\section{Blood samples and measurements:}

Jugular blood samples were taken from overnight fasting lambs (12 hrs. fasting) in the morning (8:00 a.m.), at the beginning of the experiment (day 0) and, subsequently, every month to determine serum concentrations of total protein, albumin, and cortisol. Blood samples were collected in $10-\mathrm{ml}$ vacuum tubes and centrifuged for $15 \mathrm{~min}$ at $3500 \mathrm{rpm}$. After blood serum recovery, metabolites were determined using a spectrophotometer and ELISA. Serum concentrations of total protein, and albumin were measured using commercial colorimetric assay kits (Egyptian Company for Biotechnology, Cairo. Egypt). Absorbance was monitored using a spectrophotometer (Unico UV-2000, Spectra Lab Scientific Inc., USA) set at a wavelength of 560nm and $578 \mathrm{~nm}$ for total protein, and albumin, respectively.

Cortisol levels were estimated using ABNOVA ${ }^{\circledR}$ Sheep cortisol ELISA kits. The manufacturer's instructions were followed in performing the test. Briefly, $40 \mu \mathrm{L}$ of cortisol standard and sera samples were pipetted into micro wells coated with cortisol $\mathrm{mAb}$. Cortisol enzyme conjugate $(200 \mu \mathrm{L})$ was added to all the wells and incubated for 60 mins at room temperature while shaking in the process. The contents of the wells were discarded after incubation and $300 \mu \mathrm{L}$ of wash buffer was used to wash 3 times and blotting on absorbent paper towel each time. One hundred microliters of TMB substrate was added to each well and incubated for 15 mins at room temperature and shaken during the process. Thereafter, $50 \mu \mathrm{L}$ of stop solution was added, gently mixed and read within 20 mins at $450 \mathrm{~nm}$ using an ELISA reader. The ELISA kits had a sensitivity of $0.1 \mathrm{ng} / \mathrm{ml}$ and specificity of $100 \%$.

\section{Statistical analysis:}

Data were analyzed using the Statistical Analyses System (SAS, 2013, version 9.4, SAS Institute Inc., Cary, NC, USA), and tested for normality prior to analysis by examination of normal distribution plots and transformed when necessary. The effect of 
treatments on bedding measurements, animals' performance and blood parameters were analyzed using the analysis of variance with time (month or day) as repeated measure according to the following model. Yijk $=\mu+\mathrm{P}_{\mathrm{i}}+\mathrm{B}_{\mathrm{k}}+\varepsilon_{\mathrm{ik}}+\mathrm{T}_{\mathrm{j}}+\mathrm{PT}_{\mathrm{ij}}+\delta_{\mathrm{ijk}}$. Where, $\mathrm{Yij}=$ the observation, $\mu=$ overall mean, $\mathrm{Pi}=$ effect of the period, Bk = effect of block, cik = effect of the period error, $\mathrm{Tj}=\mathrm{e} \square$ ect of the treatments, PTij= effect of the interaction between period and treatments, $\delta \mathrm{ijk}=$ effect of the treatments error. For the fleece scores were analyzed using an analysis of variance, with treatment as fixed effect and residual as random effect according to the following model. $\mathrm{Y}_{\mathrm{ij}}=\mu+\mathrm{B}_{\mathrm{i}}+\mathrm{T}_{\mathrm{j}}+\varepsilon_{\mathrm{ij}}$. Where $\mathrm{Y}_{\mathrm{ij}}=$ the observation, $\mu$ $=$ overall mean, $B_{i}=$ effect of block, $T_{j}=e \square$ ect of the treatment, $\varepsilon \mathrm{ij}=$ effect of the error related to individual observation. The comparisons between different bedding type and different time were done using Duncan multiple range test, while the interactions were tested using Ls means with PIDFF procedure.

\section{RESULTS}

\section{Physical characteristics of different bedding materials:}

The Surface temperature of bedding materials significantly $(\mathrm{P}<0.05)$ differ between bedding materials during August and September (high temperature months). Therefore, Sand has lower Surface temperature (Table 1) compared with both rice straw and wood shavings. However, rice straw and wood shavings had similar surface temperature during the same period. In addition, during the low temperature months (October to December) there were no differences in Surface temperature between bedding materials. Moreover, there were no differences between front, middle and rare surface temperature for the same pen.

Table 1. Physical characteristic of sand, rice straw and wood shavings as bedding materials

\begin{tabular}{|c|c|c|c|}
\hline & Sand & Straw & Wood \\
\hline \multicolumn{4}{|l|}{ Surface temperature $\left(C^{\circ}\right)$} \\
\hline August & $36.40 \pm 0.08^{\mathrm{b}}$ & $37.61 \pm 0.01^{\mathrm{a}}$ & $37.60 \pm 0.01^{\mathrm{a}}$ \\
\hline September & $30.21 \pm 0.40^{\mathrm{b}}$ & $31.63 \pm 0.58^{\mathrm{a}}$ & $32.15 \pm 0.82^{\mathrm{a}}$ \\
\hline October & $25.34 \pm 0.29$ & $26.21 \pm 0.37$ & $26.38 \pm 0.41$ \\
\hline November & $23.35 \pm 0.29$ & $22.95 \pm 0.27$ & $23.76 \pm 0.27$ \\
\hline December & $20.74 \pm 0.13$ & $21.19 \pm 0.14$ & $20.73 \pm 0.19$ \\
\hline \multicolumn{4}{|l|}{ cleanliness score } \\
\hline D7 & $4.68 \pm 0.02$ & $4.57 \pm 0.04$ & $4.55 \pm 0.02$ \\
\hline D14 & $4.55 \pm 0.03$ & $4.28 \pm 0.05$ & $4.35 \pm 0.04$ \\
\hline $\mathrm{D} 21$ & $4.50 \pm 0.06$ & $4.24 \pm 0.04$ & $4.35 \pm 0.04$ \\
\hline D28 & $4.48 \pm 0.06$ & $4.18 \pm 0.03$ & $4.08 \pm 0.05$ \\
\hline Overall & $4.55 \pm 0.03$ & $4.25 \pm 0.05$ & $4.33 \pm 0.04$ \\
\hline \multicolumn{4}{|l|}{ pH value } \\
\hline D0 & $7.80 \pm 0.01^{\mathrm{a}}$ & $7.21 \pm 0.01^{\mathrm{b}}$ & $5.10 \pm 0.01^{\mathrm{c}}$ \\
\hline D7 & $8.20 \pm 0.01^{\mathrm{a}}$ & $7.62 \pm 0.01^{b}$ & $6.49 \pm 0.01^{\mathrm{c}}$ \\
\hline D14 & $8.58 \pm 0.02^{\mathrm{a}}$ & $7.98 \pm 0.03^{b}$ & $7.87 \pm 0.01^{\mathrm{c}}$ \\
\hline D21 & $8.71 \pm 0.01^{\mathrm{a}}$ & $8.03 \pm 0.04^{b}$ & $8.09 \pm 0.02^{b}$ \\
\hline D28 & $9.01 \pm 0.02^{\mathrm{a}}$ & $8.50 \pm 0.04^{\mathrm{c}}$ & $8.64 \pm 0.01^{\mathrm{b}}$ \\
\hline Overall & $8.46 \pm 0.08^{a}$ & $7.87 \pm 0.08^{b}$ & $7.24 \pm 0.24^{c}$ \\
\hline \multicolumn{4}{|l|}{ Absorbency \% } \\
\hline D0 & $30.03 \pm 0.04^{c}$ & $195.86 \pm 2.46^{\mathrm{a}}$ & $147.23 \pm 4.92^{b}$ \\
\hline D7 & $30.08 \pm 0.06^{\mathrm{c}}$ & $200.27 \pm 7.64^{\mathrm{a}}$ & $150.34 \pm 2.84^{b}$ \\
\hline D14 & $30.06 \pm 0.07^{\mathrm{c}}$ & $194.61 \pm 5.62^{\mathrm{a}}$ & $145.40 \pm 4.36^{\mathrm{b}}$ \\
\hline $\mathrm{D} 21$ & $30.14 \pm 0.09^{c}$ & $197.06 \pm 2.16^{\mathrm{a}}$ & $147.77 \pm 2.26^{b}$ \\
\hline D28 & $29.92 \pm 0.09^{c}$ & $189.85 \pm 4.16^{\mathrm{a}}$ & $151.34 \pm 4.12^{b}$ \\
\hline Overall & $30.05 \pm 0.03^{c}$ & $195.53 \pm 2.11^{\mathrm{a}}$ & $148.41 \pm 1.64^{b}$ \\
\hline \multicolumn{4}{|l|}{ Dry matter \% } \\
\hline D7 & $97.09 \pm 0.48^{\mathrm{a}}$ & $80.62 \pm 1.59^{b}$ & $80.69 \pm 1.29^{b}$ \\
\hline D14 & $96.97 \pm 0.31^{\mathrm{a}}$ & $79.77 \pm 0.71^{\mathrm{c}}$ & $83.31 \pm 2.56^{\mathrm{b}}$ \\
\hline $\mathrm{D} 21$ & $97.15 \pm 0.24^{\mathrm{a}}$ & $80.67 \pm 0.85^{b}$ & $80.21 \pm 1.32^{b}$ \\
\hline D28 & $97.16 \pm 0.36^{\mathrm{a}}$ & $81.78 \pm 0.39^{b}$ & $80.17 \pm 0.71^{\mathrm{b}}$ \\
\hline overall & $97.09 \pm 0.17^{\mathrm{a}}$ & $80.71 \pm 0.49^{b}$ & $81.10 \pm 0.80^{b}$ \\
\hline
\end{tabular}

Different letters $(\mathrm{a}, \mathrm{b}, \mathrm{c})$ represent significant differences among treatments

Bedding materials lasted for one month in each pen before the complete replacement, during this month bedding cleanliness was recorded weekly, the bedding cleanliness did not differ $(\mathrm{P}>0.05$; Table 1$)$ between different bedding materials. During the experiment it have noticed that, to keep pens clean and contaminated free more sand was added with time passed compare with rice straw and wood shavings. 
The $\mathrm{pH}$ values increased as time passed for all the three bedding materials (Table 1). From day 0 sand had the highest $(\mathrm{P}<0.05) \mathrm{pH}$ value while, wood shaving had the lowest $\mathrm{pH}$ value. The rice straw bedding had an intermediate $\mathrm{pH}$ value, these differences continued through day 7, 14, 21 and day28. Both bedding materials absorbency and Dry matter did not differ with use. On the other hand, bedding type affect bedding materials absorbency and dry matter. Therefore, sand had the highest $(\mathrm{P}<0.01)$ dry matter and lowest $(\mathrm{P}<0.05)$ absorbency. In contrast, rice straw had the highest $(\mathrm{P}<0.05)$ absorbency but the dry matter was similar to wood shavings.

\section{Lambs'performance.:}

Means \pm standard error for productive performance of growing lambs on three types of bedding substrates are listed in Table (2). Lambs in sand bedding group showed an improvement in growth performance compared with the other two groups. As a result, lambs in sand group consume more ( $\mathrm{P}$ $<0.01$ ) dry matter (both concentrate mixture and wheat straw intake were higher) than rice straw and wood shavings groups. Moreover, lambs in rice straw groups consume more $(\mathrm{P}<0.01)$ dry matter (concentrate mixture) than lambs in wood shavings group. On the other hand, the wheat straw consumption was similar between the lambs in the two groups of rice straw and wood shavings. Also, lambs in sand group efficiently $(\mathrm{P}<0.05)$ converted dry matter intake to daily gain compared with lambs in the other two groups. In contrast, no differences were found in feed efficiency between rice straw and wood shavings treatment groups. The body weight and daily gain of lambs during the first month were not different among treatment groups. From the second month to the end of the experiment lambs in sand group had greater $(\mathrm{P}<0.05)$ daily gain compared to lambs in the other two groups. Also, daily gain of lambs in rice straw group was higher $(p<0.05)$ than those in wood shavings group. Increased daily gain of lambs in sand group led to heavier $(\mathrm{P}<0.05)$ final body weight than the other two groups. Although, lambs in rice straw group had significant greater daily gain compared with wood shavings group, the difference in final body weight was not significant (Table 2). Fleece score varied $(\mathrm{P}<0.01)$ in different bedding types (Table 2). In addition, fleece score was cleaner for lambs bedded with sand compared with those bedded with organic materials (wood shavings and rice straw). Also, wood shavings improved $(\mathrm{P}<0.01)$ lambs fleece score compared with rice straw.

Table 2. Effect of different bedding materials on lambs' performance

\begin{tabular}{|c|c|c|c|}
\hline & Sand & Wood shavings & Rice straw \\
\hline Fleece score & $1.50 \pm 0.03^{c}$ & $2.20 \pm 0.05^{\mathrm{a}}$ & $1.72 \pm 0.03^{b}$ \\
\hline Dry mater intake $(\mathrm{kg} / \mathrm{d})$ & $1.41 \pm 0.05^{\mathrm{a}}$ & $0.98 \pm 0.03^{c}$ & $1.05 \pm 0.03^{\mathrm{b}}$ \\
\hline Concentrate mixture intake $(\mathrm{kg} / \mathrm{d})$ & $1.10 \pm 0.04^{\mathrm{a}}$ & $0.76 \pm 0.02^{\mathrm{c}}$ & $0.82 \pm 0.02^{\mathrm{b}}$ \\
\hline Wheat straw intake $(\mathrm{kg} / \mathrm{d})$ & $0.47 \pm 0.02^{\mathrm{a}}$ & $0.33 \pm 0.01^{\mathrm{b}}$ & $0.35 \pm 0.01^{\mathrm{b}}$ \\
\hline Feed conversion ratio & $8.26 \pm 0.05^{\mathrm{b}}$ & $8.74 \pm 0.05^{\mathrm{a}}$ & $8.76 \pm 0.07^{\mathrm{a}}$ \\
\hline Initial body weight (kg) & $26.42 \pm 1.01$ & $26.40 \pm 1.54$ & $26.40 \pm 1.17$ \\
\hline Final body weight $(\mathrm{kg})$ & $52.07 \pm 1.96^{\mathrm{a}}$ & $43.20 \pm 2.51^{\mathrm{b}}$ & $44.33 \pm 1.97^{\mathrm{b}}$ \\
\hline Average daily gain $(\mathrm{g})$ & $171.08 \pm 5.75^{\mathrm{a}}$ & $112.01 \pm 3.65^{\mathrm{c}}$ & $119.44 \pm 3.21^{\mathrm{b}}$ \\
\hline
\end{tabular}

Different letters $(a, b, c)$ represent significant differences among treatments.

\section{Blood parameters:}

The effect of different bedding types on serum total protein, Albumin, globulin and cortisol concentrations are shown in Figure 1. Both time and the interaction of time with bedding type had no effect on blood parameters. Also, serum globulin concentration was similar in the three bedding types. The Serum total protein, albumin and cortisol levels were higher $(\mathrm{P}<0.05)$ in wood shavings group than the two other groups. Also, rice straw bedding group had higher $(\mathrm{P}<0.05)$ serum albumin than sand bedding group. All the differences in blood parameters due to bedding types are appeared at the end of the first month and continued to the end of the experiment.

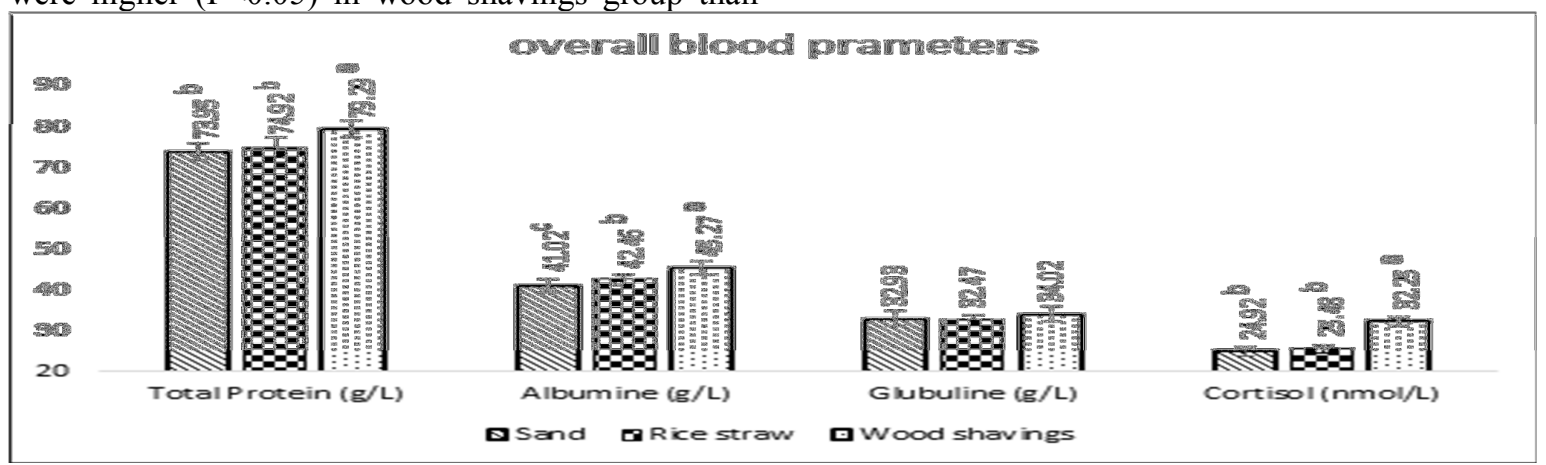

Fig. 1. Effect of different bedding types on lambs' serum total protein (A), albumin (B), cortisol (C) and the overall mean. 


\section{DISCUSSIONS}

\section{Bedding materials physical characteristics:}

Sand as bedding materials showed a good physical characteristics and improved lambs performance during the growing period compared with rice straw and wood shavings. This improvement in sand physical characteristics is mainly because its nature as inorganic material (Stowell and Inglis, 2000).

Absorbency and dry mater are very important physical characteristics of any bedding materials, where they control the moisture content of the bedding materials. Sand as inorganic bedding material has low absorbency and high dry mater compared with organic materials. Mainly this is due to, small sand's particle size, which vary from 0.1 to $1 \mathrm{~mm}$. Moreover, sand has uniform practical size (Schoonmaker, 2003). Both small and uniform practical size are necessary for animal comfort, and control sand moisture content (Stowell and Inglis, 2000). Uniform particle Size allows for adequate drainage of urine or other moisture through sand layers. Moreover, moisture on the sand surface needs short time to evaporate (Stowell and Inglis, 2000). This is due to the way that moisture connects to single grains of sand. Subsequently, the top layer of sand is quickly draying. Similar results of sand absorbency were reported by Zdanowicz et al. (2004). Moreover, DM of sand did not change as time passed because sand allows drainage of urine and other fluids (Schoonmaker,2003) while the organic materials absorb urine. Another important physical characteristic of bedding materials is $\mathrm{pH}$ value, which is substantial factor for bacterial population growth in bedding materials. In the present study, the differences in $\mathrm{pH}$ values with time and between bedding materials were due to ammonia from urine and the physical properties of the bedding types. Where, Meng et al. (2015) reported that, high ammonia content in a bedding system causes a high $\mathrm{pH}$ value. The high $\mathrm{pH}$ values observed in sand bedding may be due its good permeability for ammonia. Where, it is supposed that, the $\mathrm{pH}$ values reflect the ammonia content of deep litter, which is mainly, came from animal feces and urine. The $\mathrm{pH}$ for wood shavings and long rice straw was similar to those reported by Ward et al. (2001).

Another advantage of sand as bedding material is low surface temperature in hot weather. In addition, sand bedding temperature variesbe among seasons because of changing of the environmental temperature (Thoreson et al., 2006). Consequently, Sand has the ability to provide cooler surface in high temperature environment which allows it to carry out heat away from animals' body (Bernard et al., 2003).

\section{Blood parameters:}

Lambs blood parameters indicated that wood shavings are uncomfortable bed type for lambs. While, sand is the most comfortable bedding material in the current study. Cook (2009) stated that, increased lying time can be considered as a sign of good comfort. In Many studies using sand as bedding materials increased laying time compared with other bedding materials (Calamari et al. 2009 and Cook 2010). Moreover, animals that are housed in uncomfortable stalls will encounter stress, whereas the animals lose their desire to lay down. Subsequently, this negatively affect other desired behaviors like feeding and drinking behavior. In addition, stress resulted from uncomfortably stalls negatively influence some blood hormones concentrations. Where, ACTH concentrations (Munksgaard and Simonsen, 1996), cortisol response to ACTH challenge and growth hormone concentrations are negatively affected during stress (Munkgaard and Løvendahl 1993 and Cook, 2009). Increased plasma cortisol level in lambs bedded with sawdust compared with other bedding materials had been reported by Teixeira et al.(2015). High-serum total protein and albumin observed in the lambs bedded with wood shavings in the present study may have been related to a mild dehydration. Albumin can diminish in situations of low protein intake, as usually occurs in heat stress conditions where the animals have lower feed intake, thus the dehydration takes on more transcendence to explain the rise in albumin. Globulins concentration did not change what suggests metabolic adaptation to maintain plasma oncotic pressure.

\section{Lambs performance:}

Wood shavings effects on DMI, final weight, average daily gain and feed conversion were similar to those found in calves by Panivivat et al. (2004). On the contemporary to the current study, Panivivat et al. (2004) found a slight performance improvement in calves bedded with wheat straw compared with those bedded with sand. Also, Wolf et al. (2010) reported an increase in the feed intake, daily gain and final weight in lambs bedded with straw compared with those bedded with woodshop. The improvement in lambs' performance in sand bedded group may be mainly due to that animals bedded with sand have longer lying times than those bedded with other materials (Calamari, et al., 2009 and Cook, 2009). Moreover, Teixeira et al. (2012) found a significant increase in laying time of lambs bedded with straw compared to wood shavings. Consequently, increased laying times have several positive effects on animal performance. Firstly, increased lying times increases rumination. As a result, increased rumination, reducing forage particle size (Maulfair et al. 2010; Robbins 1983; Spalinger and Robbins 1986), which allows gut microorganisms greater access to cell wall 
carbohydrates (Robbins 1983). Also, affect the rate of particle size degradation, which in turn affects rate of digestion and rumen turnover (Van Soest 1994). Because rumen turnover encompasses the rate of ingest disappearance through digestion and passage of remaining matter to the hindgut, rumen turnover influences food intake (Short, 1975).

Secondly, increased laying time has a positive influence on several hormones levels (Drissler et al., 2005; Calamari et al., 2009 and Cook, 2009). Where, it influences the ACTH concentrations and increases the cortisol (stress hormone) response to abnormal ACTH levels, which increases the capability of the animal to overcome stress effects (Drissler et al., 2005; Calamari et al., 2009; Cook, 2009). In addition, positive influence on growth hormone concentrations has been reported in case of adequate rest (Drissler et al., 2005; Calamari et al., 2009 and Cook, 2009).

One of the main advantages of sand its nature as an inorganic and as such, does not support bacterial growth. Many studies support this fact, in dairy cow (Kristula et al., 2005 and Bernard et al., 2003).Also, low bacterial growth had been associated with using sand as bedding materials in neonatal calf (Hogan et al., 1989 and Leigh, 1999). In general, bacterial populations in inorganic bedding material such as sand are usually lower than in organic materials (Bramley and Dodd, 1984). low bacterial count helps to control infections (Fairchild et al., 1982) and infectious diseases (Hogan et al., 1989), improving animal health and performance.

Fleece cleanliness is mostly depending on bedding material absorbency and top layer dryness. low absorbency and rapid dryness of sand top layer contribute in keeping lambs fleece cleaner than those bedded with rice straw or wood shavings.

\section{CONCLUSION}

The different bedding types had varying physical characteristics and alter the lambs comfort and performance in different manners. Sand, with its natural qualities of comfort, low bacterial count and ability to detract both heat and moisture away from the animals can be able to improve animal comfort and performance and can be considered a good bedding material for lambs during growing period.

\section{ACKNOWLEDGEMENT}

This work was supported by Faculty of Agriculture, Assiut University, Assiut, Egypt.

\section{REFERENCES}

Allison, F. E. and M.S. Anderson, 1951. The use of sawdust for mulches and soil improvement. U.S.D.A. Cir. 891.

Bernard, J. K., D. R. Bray, and J. W. West, 2003. Bacterial concentrations and sand usage in free stalls bedded with fresh or recycled sand. Pp.
001-008 in Fifth International Dairy Housing Proceedings of the 29-31 January 2003 Conference (Fort Worth, Texas USA). Online. Available:

http://elibrary.asabe.org/abstract.asp?aid=11594\& $\mathrm{t}=1$

Bewley, J., R.W. Palmer, and D.B. Jackson-Smith, 2001. A comparision of free-stall barns used by modernized Wisconsin dairies. J. Dairy Sci., 84:528-541.

Bollen, W. B. and K.C. Lu, 1957. Effect of Douglasfir sawdust mulches and incorporations on soil microbial activities and plant growth. Proc. Soil Sci. Am., 21:35-41.

Bramley, A. J. and F.H. Dodd, 1984. Reviews of the progress of dairy science: mastitis control-progress and prospects. J. Dairy Res., 51(3):481512.

Calamari, L., F. Calegari, and L. Stefanini, 2009. Effect of different free stall surfaces on behavioural, productive and metabolic parameters in dairy cows. Appl. Anim. Behav. Sci., 120:9-17.

Cook, N. B, 2009. Free stall Design for Maximum Cow Comfort. Pages 255 - 268 in Western Canadian Dairy Seminar Advances in Dairy Technology. Vol. 21.

Cook, N. B, 2010. Subject: Big sand stalls: best thing ever or bad idea? Accessed 12 March 2015.

Drissler, M., M. Gaworski, C. B. Tucker, and D. M. Weary, 2005. Freestall maintenance: effects on lying behavior of dairy cattle. J. Dairy. Sci., 88:2381- 2387.

Ericsson, K. and L. J. Nilsson, 2006. Assessment of the potential biomass supply in Europe using a resource-focused approach. Biomass Bioenerg., 30:1-15.

Fairchild, T. P., B. J. McArthur, J. H. Moore, and W. E. Hylton, 1982. Coliform counts in various bedding materials. J. Dairy Sci., 65:1029-1035.

Gordon, G. D. H. and M. S. Cockram, 1995. A comparison of wooden slats and straw bedding on the behaviour of sheep. Anim. Welf., 4:131-134.

Hadley, P. J., J. S. Holder, and M. H. Hinton, 1997. Effects of fleece soiling and skinning method on the microbiology of sheep carcases. Vet. Rec., 140:570-574.

Hogan, J. S., K.L. Smith, K.H. Hoblet, D.A. Todhunter, P.S. Schoenberger, W.D. Hueston, D.E. Pritchard, G.L. Bowman, L.E. Heider, B.L. Brockett, and H.R. Conrad, 1989. Bacterial counts in bedding materials used on nine commercial dairies. J. Dairy Sci. 72(1):250-258.

Kristula, M. A., W. Rogers, J.S. Hogan, and M. Sabo, 2005. Comparison of bacteria populations in clean and recycled sand used for bedding in dairy facilities. J. Dairy. Sci., 88(12):4317-4325.

Kudva, I. T., K. Blanch, and C. J. Hovde, 1998. Analysis of Escherichia coli $\mathrm{O} 157: \mathrm{H} 7$ survival in ovine or bovine manure and manure slurry. Appl. Environ. Microbiol., 64:3166-3174.

Leigh, J. A., 1999. Streptococcus uberis: A Permanent Barrier to the Control of Bovine 
Mastitis? Vet J., 157 (3):225-238.

Maulfair, D. D., G.I. Zanton, M. Fustini, and A.J. Heinrichs, 2010. Effect of feed sorting on chewing behavior, production, and rumen fermentation in lactating dairy cows. J. Dairy. Sci., 93:4791-4803.

McGreevy, P. D., S. George, and P.C. Thomson, 2007. A note on the effect of changes in flooring on the behaviour of housed rams. Appl. Anim. Behav. Sci., 107:355-360.

Menga, J., F.H. Shia, Q.X. Meng, L.P. Ren, Z.M. Zhou, H. Wu, and L.P. Zhao, 2015. Effects of bedding material composition in deep litter systems on bedding characteristics and growth performance of limousin calves. Asian Australas. J. Anim. Sci., 28(1 ):143-150.

Miller, J. J., E.C.S. Olson, D.S. Chanasyk, B.W. Beasley, L.J. Yanke, F.J. Larney, T.A. McAllister, B.M. Olson, and L.B. Selinger, 2006. Bedding and Within-Pen Location Effects on Feedlot Pen Runoff Quality Using a Rainfall Simulator. J. Environ. Qual., 35:105-115.

Munksgaard, L. and H.B. Simonsen, 1996. Behavioral and pituitary adrenal-axis responses of dairy cows to social isolation and deprivation of lying down. J. Anim. Sci., 74:769-778.

Munksgaard, L. and P. Løvendahl, 1993. Effects of social and physical stressors on growth hormone levels in dairy cows. Can. J. Anim. Sci., 73:847853.

Nimenya, H., A. Delaunois, S. Bloden, D. La Duong, B. Canart, B. Nicks, P. Gustin, and M. Ansay, 2000. In vitrio short-term study ofammoniumnitrogen production from cattle urine: Influence ofampicillin, hydroquinone and animal litter materials. J. Agric. Sci., 135:57-64.

Norring, M., E. Manninen, A. M. de Passillé, J. Rushen, and H. Saloniemi, 2010. Preferences of dairy cows for three stall surface materials with small amounts of bedding J. Dairy Sci., 93:70-74.

O'Connell, J. M. and W. J. Meaney, 1997. Comparison of shredded newspaper and sawdust as bedding for dairy cows: behavioural, clinical and economic parameters. Irish Vet. J., 50:167170.

Panivivat, R., E.B. Kegley, J.A. Pennington, D.W. Kellogg, and S.L. Krumpelman, 2004. Growth Performance and Health of Dairy Calves Bedded with Different Types of Materials. J. Dairy Sci., 87(11):3736 - 3745 .

Robbins, C. T, 1983. 13 - Digestion and Nutrient Metabolism. Pages 274-312 in Wildlife Feeding and Nutrition. Academic Press.

SAS, 2013. SAS/SAT User's Guide. Statistics Analysis Institute, Cary, NC,USA.

Schoonmaker, K, 2003. Subject: Maximize the comforts of sand, Dairy Herd Management. Accessed 22 March 2013, 2013.

Short, H. L, 1975. Nutrition of southern deer in different seasons. J. Wildlife. Manage., 39:321329.

Spalinger, D. E. and C.T. Robbins, 1986. The assessment of handling time in ruminants: the effect of plant chemical and physical structure on the rate of breakdown of plant particles in the rumen of mule deer and elk. Can. J. Zoolog., 64:312-321.

Stowell, R. R. and S. Inglis, 2000. Sand for Bedding. Pages 226-234 in Dairy housing and equipment systems: managing and planning for profitability Natural Resource, Agriculture and EngineeringSe rvice,Ithaca,NY CampHill, PA. NRAES-129.

Teixeira, D. L., G. C. Miranda-de la Lama, M. Villarroel, S. Garcia-Belenguer, C. Sañudo, and G. A. María, 2012. Effect of straw on lamb welfare, production performance and meat quality during the finishing phase of fattening. Meat Sci., 92:829-836

Teixeira, D. L., G. Miranda-de la Lama, M. Villarroel, J. L. Olleta, S. GarcÃa-Belenguer, J. $\operatorname{Esc} \tilde{A}^{3} \mathrm{~s}$, and G. A. MarÃa, 2015. Effects of alternative bedding substrates on lamb welfare, productive performance, and meat quality during the finishing phase of fattening. J. Vet. Sci., 10(2):171-178. Online. Available: http://dx.doi.org/10.1016/j.jveb.2014.12.011

Teixeira, D. L., G.C .Miranda-de la Lama, M. Pascoal-Alonso, L. Aguayo-Ulloa, M. Villarroel, and G.A. Maria, 2013. A note on lamb's choice for different types of bedding materials. J. Vet. Behav., 8:175-179.

Teixeira, D. L., M. Villarroel, and G.A. Maríaa, 2014. Assessment of different organic beddings materials for fattening lamb. Small Ruminant Res., 119 22-27.

Thoreson, D. R., D.C. Lay, and L.L. Timms, 2006. Dairy Free Stall Preference Field Study. Iowa State University.

Tuyttens, F. A. M., 2005. The importance of straw for pig and cattle welfare: A review. Appl. Anim. Behav. Sci., 92:261-282.

Van Soest, P. J., 1994. Nutritional Ecology of the Ruminant. Cornell University Press, Ithaca, New York.

Ward, P. L., J.E. Wohlt, and S.E. Katz, 2001. Chemical, physical, and environmental properties of pelleted newspaper compared to wheat straw and wood shavings as bedding for horses. J. Anim. Sci., 79:1359-1369.

Wolf, B. T., H.R.B. Molloy, M.J. Trayte, and M. T. Rose, 2010. Behaviour of growing lambs housed on straw or woodchip bedding materials and their preference for floor type Appl. Anim. Behav. Sci., 124:45-50.

Zdanowicz, M., J.A. Shelford, C.B. Tucker, D.M. Weary, and M. A.G. von Keyserlingk, 2004. Bacterial populations on teat ends of dairy cows housed in free stalls and bedded with either sand 
or sawdust. J. Dairy Sci., 87(6):1694 -1701.

bedding materials. J. Dairy Sci., 69:1932-1941.

Zehner, M. M., R.J. Farnsworth, R.D. Appleman, K.

Lamtz, and J.A. Springer, 1986. Growth of

environmental mastitis pathogens in various

الخصائص الطبيعية لقش الأرز ونشارة الخشب والرمل كفرشة وتأثيرها علي أداء وصحة الحملان

أحمد محمد عبد الله حسين

قسم الإتتاج الحيوانس، كلية الزراعة، جامعة أسيوط

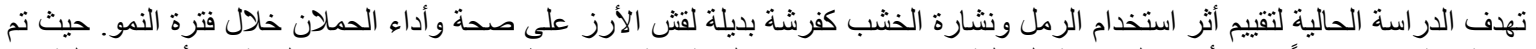

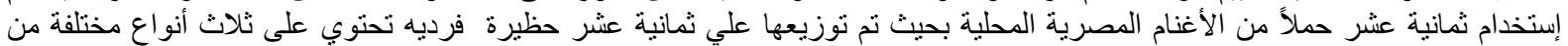

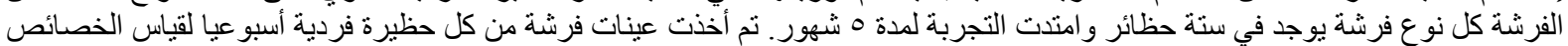

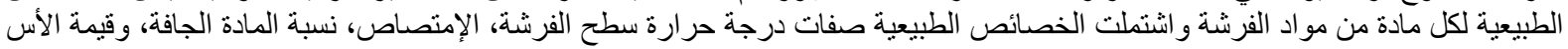

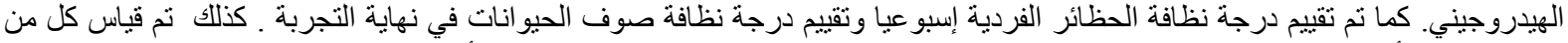

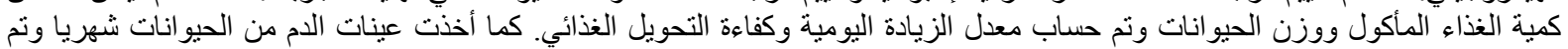

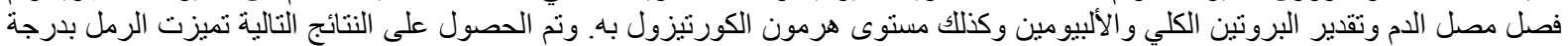

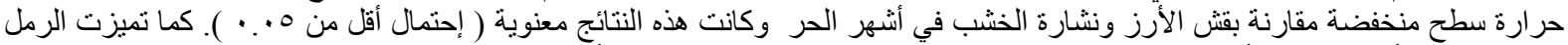

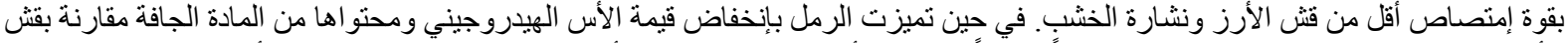

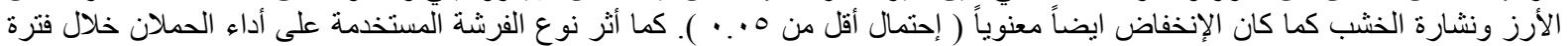

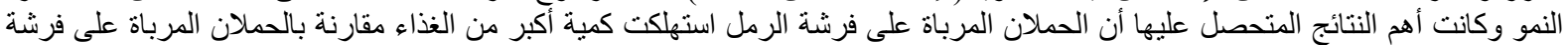

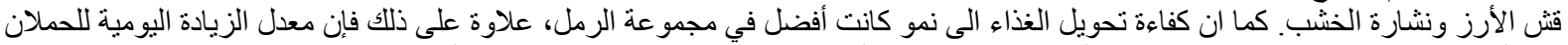

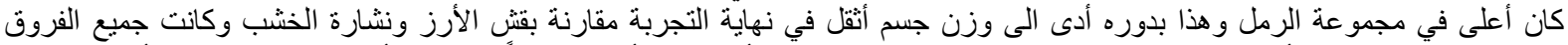

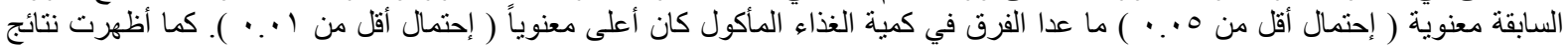

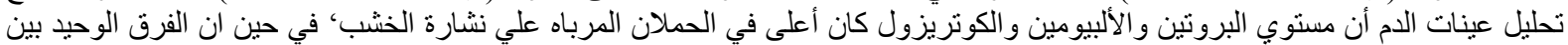

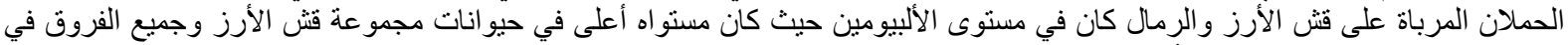

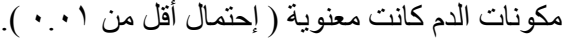

